\title{
Editorial: The Maastricht Journal at twenty
}

Citation for published version (APA):

Smits, J. M., \& Muir, E. (2013). Editorial: The Maastricht Journal at twenty. Maastricht Journal of European and Comparative Law, 20, 334-335. https://doi.org/10.1177/1023263X1302000301

Document status and date:

Published: 01/01/2013

DOI:

10.1177/1023263X1302000301

Document Version:

Publisher's PDF, also known as Version of record

\section{Please check the document version of this publication:}

- A submitted manuscript is the version of the article upon submission and before peer-review. There can be important differences between the submitted version and the official published version of record.

People interested in the research are advised to contact the author for the final version of the publication, or visit the DOI to the publisher's website.

- The final author version and the galley proof are versions of the publication after peer review.

- The final published version features the final layout of the paper including the volume, issue and page numbers.

Link to publication

\footnotetext{
General rights rights.

- You may freely distribute the URL identifying the publication in the public portal. please follow below link for the End User Agreement:

www.umlib.nl/taverne-license

Take down policy

If you believe that this document breaches copyright please contact us at:

repository@maastrichtuniversity.nl

providing details and we will investigate your claim.
}

Copyright and moral rights for the publications made accessible in the public portal are retained by the authors and/or other copyright owners and it is a condition of accessing publications that users recognise and abide by the legal requirements associated with these

- Users may download and print one copy of any publication from the public portal for the purpose of private study or research.

- You may not further distribute the material or use it for any profit-making activity or commercial gain

If the publication is distributed under the terms of Article $25 \mathrm{fa}$ of the Dutch Copyright Act, indicated by the "Taverne" license above, 


\title{
EDITORIAL
}

\section{THE MAASTRICHT JOURNAL AT TWENTY}

\author{
ELISE Muir and JAN SMITS*
}

This special issue of the Maastricht Journal of European and Comparative Law celebrates the $20^{\text {th }}$ anniversary of its founding. When the Maastricht Journal was established in 1994 it was one of the first journals devoted to the emerging ius commune Europaeum. There is no doubt that at that time there was already a considerable number of journals devoted to either European law or comparative law, but they all lacked the focus on the common roots and principles upon which the European legal systems are based. The Maastricht Journal aimed to fill this gap. The editorial board is proud to say that in hindsight this has proved to be a highly visionary choice. In 1994 one could not foresee how topical thinking about the common law of Europe would become. The Journal has followed this development closely and has offered a forum for both endorsement and critique of the Europeanization of law. Today the Maastricht Journal is no longer the only journal devoted to the study of the common law of Europe. But it is still unique in its focus on both European law and the Europeanization of substantive fields such as private law, constitutional law, criminal law, environmental law, and so on.

The $20^{\text {th }}$ anniversary of the Journal calls for something special. It is a happy coincidence that 2013 is also the year in which the entry into force of the Maastricht Treaty on European Union is celebrated. This Treaty has intensified the European integration process. Since then, the substantive scope of European Union law has expanded even further, while the institutional mechanisms supporting this process were being modernized. This double expansion and modernization process is so broad and complex that it has become almost impossible for a single and isolated observer to keep an accurate overview of the essential characteristics of the EU legal order. The $20^{\text {th }}$ anniversary seemed like an excellent occasion to constitute a platform for bringing together the knowledge of experts in selected sub-disciplines of EU substantive law and asking them to explore their own field of expertise in light of a joint set of research questions. These questions focus on the general dynamics of their discipline so as to critically reflect on the Europeanization process at the core of the Journal's scope.

True to the Journal's mission from the very beginning, the present issue is thus an exercise at the intersection of European law and the substantive fields. From the European

Maastricht University. 
law perspective it could be coined as 'applied institutional law', while for lawyers active in substantive fields it is about the Europeanization of their discipline.

The first facet of this approach involved selecting several areas of EU substantive law that would be examined in search of common trends and/or divergences. We opted for a sample of economic and non-economic policies, representing both old as well as more recent competences, thus seeking to reflect the diversity of contemporary EUcompetences. While the first articles by Pablo Ibáñez Colomo, Jules Stuyck and Alexandre de Streel are respectively devoted to EU competition law, EU consumer law and EU economic and monetary policy - thereby illustrating the dynamics of EU economic law and governance - the subsequent three contributions focus on non-economic law with enquiries into EU environmental law by Astrid Epiney, EU migration law by Anja Wiesbrock and EU criminal law by Ester Herlin-Karnell.

The second facet of this initiative consisted of identifying common research questions that would be used to highlight general dynamics in the process of European integration in the last 20 years. The questionnaire is both simple and flexible, so as to leave enough of a margin of manoeuvre for our contributors to emphasize the specificities of their own discipline. All of the questions are of an institutional nature; they invite the contributors to put into perspective their own field of expertise, and identify prominent and innovative mechanisms susceptible of being relevant to other areas of EU law or actually unique to their specific discipline. The authors were thus invited to reflect on the three key stages through which EU law comes to life, and is being shaped and activated: in other words, all authors enquired into (i) the sources of EU law, (ii) regulatory processes and (iii) enforcement mechanisms. The exact questions to the contributors were:

(1) Has there been an innovative use of sources of EU law (especially general principles of EU law) in your field over the last 20 years? If not, why? If yes, what sources (or which general principles) have had a prevalent role?

(2) To what extent has the field of EU law under scrutiny contributed to regulatory innovation for EU governance?

(3) Has there been a reflection, in your field, on how to modernize enforcement mechanisms? What are the key outcomes?

Finally, we invited Bruno de Witte, who has been reflecting on European integration for more than 20 years and who has been associated with the Journal since it was founded, to draw conclusions from this collective research exercise. 